\title{
Evaluating the Gaps Competence of Graduate Office Administration and Secretary Program Using Importance-Performance Analysis in an Indonesian First-ranked University
}

\section{Sancoko, Moh. Riduansyah, Puput Leni Yuliani, and Wahyu Nofiantoro}

Vocational Education Program, Universitas Indonesia

\section{Abstract}

Objectives: This study aims to describe the competence quality of undergraduate office administration \& secretary program by using Importance-Performance Analysis.

Methods: This research is a descriptive analysis with quantitative approach. The descriptive analysis is used to describe alumni's perceptions of the importance and their performance for 12 competencies, while the quantitative method is used to

Corresponding Author:

Sancoko

cokoprivat@gmail.com

Received: 8 June 2018

Accepted: 17 July 2018

Published: 8 August 2018

Publishing services provided by Knowledge E

(c) Sancoko et al. This article is distributed under the terms of the Creative Commons

Attribution License, which permits unrestricted use and redistribution provided that the original author and source are credited.

Selection and Peer-review under the responsibility of the 2 nd ICVHE Conference Committee. calculate the competencies that need to be improved. Results: Study results the competency gaps that alumni of office administration \& secretary program need to improve on are being more active in English and General Knowledges.

Keywords: competence, vocational, importance-performance analysis

\section{Introduction}

One of the characteristics of a country which qualified can be seen from the quality of its human resources, especially in how many communities are educated. Education becomes the focus of government in order to improve the welfare of its people. Many parties have their focus in way of education, because education is one of place to coach the labor. In addition, for some, education becomes a place to obtain employment and certain status [5].

In general, the form of Higher Education in Indonesia is divided into two types, Academic Education and Vocational Education. Based on Law Number 20 of 2003 about National Education System, Education in Indonesia is divided into 3 parts: Basic Education, Secondary Education and Higher Education. Basic education is the level of the formal education pathways that underlying the secondary education level, which is the composition of education that equates to Elementary and Junior High. Secondary 
education is the level of education in the formal education pathways which is a continuation from basic education. After graduate from Secondary Education, student can take a Higher Education whose can be a Diploma or Bachelor Education. Based on Law No. 12 of 2012 in Article 16, mentioned that a Vocational Education is a Higher Education that equates to a diploma program which more focuses the students to the jobs with applied skills until they take the applied undergraduate programs.

The Government through the Ministry of Manpower and Transmigration encourages higher education-based vocational education programs. At that time during the presidency of SBY, through 'National Mid Term Development Plan 2015', targeted in 2025 will stand 100 polytechnics and educational composition is divided into 30:70. That is, where 70 percent of education is based on vocational education, and 30 percent of other education is based on Academic. Meanwhile, in society there is often a misconception that vocational education is a schism of academic education. Actually, Vocational Education is a comprehensive and structured skills education owned by the University, Polytechnic, Academy and so on that must be connected and in accordance with industry needs.

The process of connected and in accordance with industry needs, can occur if the college can provide candidates for skilled workers, have quality competencies and in accordance with the needs of the world of work. Therefore, vocational education, are expected to play a major role in providing skilled and competent labor in an effort to improve the competitiveness of their graduates [3]. Based on Sanjaya (2009) the purpose of 'connected and in accordance with industry needs' is to bring the industry with the quality of human resources, especially related to the quality of employment.

Quality is often perceived as the physical products, and these understanding isn't appropriate. Quality can also be non-physical products such as services, output of human resources and so on. Definition for 'quality' usually describes the characteristics of a product such as performance, reliability, easy to use, and aesthetics. Quality refers to a number of product features, both on-premises and attractive features that satisfy the demand of the service recipient and thus satisfy the customer of the product. Quality consists of anything that is free from damage or fraud [1]. The quality of an education, it is good or bad, can be seen from the output generated, especially through the competence of alumni or through the complaints of users in the industry where they are working.

Competencies can be interpreted as the underlying characteristics in individual to achieve the superior performance. Competencies include knowledge, skills, and workrelated skills, as well as skills needed for work [9]. In other hand, Prasetya, Effendy, \& 
Halim (2013)said the aspects that contains in the competence are knowledge, skills, attitudes, attitudes, self-concept, values, and self-motivation/motivation. Based on that, Competencies in the industry can be interpreted as an individual characteristic related to the criteria of a particular job.

Competence is a behavior that can be arise when in certain situations individual competence is below the standards required especially in the work place. Vocational Education Program as a place to study should be watch the gap of the existing competencies with industrial needs. So that does not happen an unemployed graduate or not work according to its field.

The government is currently promoting Competence Certification for Polytechnic and vocational graduates, to improve their competencies. Office Administration and Secretary Program is one of vocational education at the Universitas Indonesia. The Environment always changes the Program to evaluate the quality of the education. One of the changes is Curriculum changes, which made to fit the relevance of knowledge, alumni's competence in the framework of facing global competition.

To improve the education process in Higher Education can be seen from 'the quality of Alumni', especially alumni who are already working in industry. Based on the description on the aforementioned background, the main problem of this research is how much gaps of competence possessed by alumni of Office Administration $\&$ Secretary Program Universitas Indonesia with industrial needs.

\section{Methods}

\subsection{Study design and setting}

The method that use in this research is descriptive analysis with quantitative approach. Descriptive analysis is a method that aims to describe or give an idea of an object of research under study through samples or data that have been collected and make conclusions which generally accepted [11].

Techniques of collecting data aims to obtain data or information that can explain or answer research problems objectively. The Technique is by doing the list of direct question to the object of research, so that data collected by author in accordance with actual situation at the time of research (cross-sectional). The questionnaire that use in this research is Indotracer version 2008. Reason for the use of this questionnaire is because the simple questionnaire which suitable for a limited time studies. 


\subsection{Data collection and analysis}

The population in this research is Alumni of Office Administration and Secretary Program Universitas Indonesia-2010. By considering the population and the limitations of time available in this research, the author using Non-probability sampling with purposive technique.

This technique is suitable for limited time studies but the minimum requirement of the sample still fulfilled [11]. The sample in this research is all Alumni of Office Administration and Secretary Program Universitas Indonesia- 2010.

Besides that, the instrument used was divided into two sections. Section I collected the general information of the alumni, while section II refers to alumni's perceptions of the importance of key attributes and their performance for these attributes.

The attributes under consideration are 12 competencies that graduates should have in office administration and secretaries field. The attributes are: General knowledge, English, Computer, Research methodology, Teamwork, Oral communication skills, written Communication skills, Community Empowerment, Specific theoretical knowledge, Specific practical knowledge, Organizational Management, and Leadership.

\subsection{Presenting the data}

The results of the study are described using the Importance-Performance Analysis (IPA) which developed by Martilla \& James in 1977. This method has proven to be a generally applicable tool which is relatively easy to administer and interpret resulting in extensive use among researchers and managers in various fields, and is a way to promote the development of effective marketing programs, because it facilitates the interpretation of data and increases usefulness in making strategic decisions $[4,10]$.

The author will describe the results of research in the form of four quadrants that are graphic and easy to interpret, which can be seen as follows:

Figure 1 shows IPA is divided into four quadrants; an A, B, C, and D quadrant. An A quadrant (Concentrate Here) illustrates that the customer considers the attribute of important so that the customer has a high expectation on that attribute. However, the company does not provide a good service to these attributes. an A quadrant suggests the company should concentrate on improving its performance on this attribute.

Quadrant B (keep up the good work), describes that attribute are considered important to customers, while the company already provides a good service to customers 


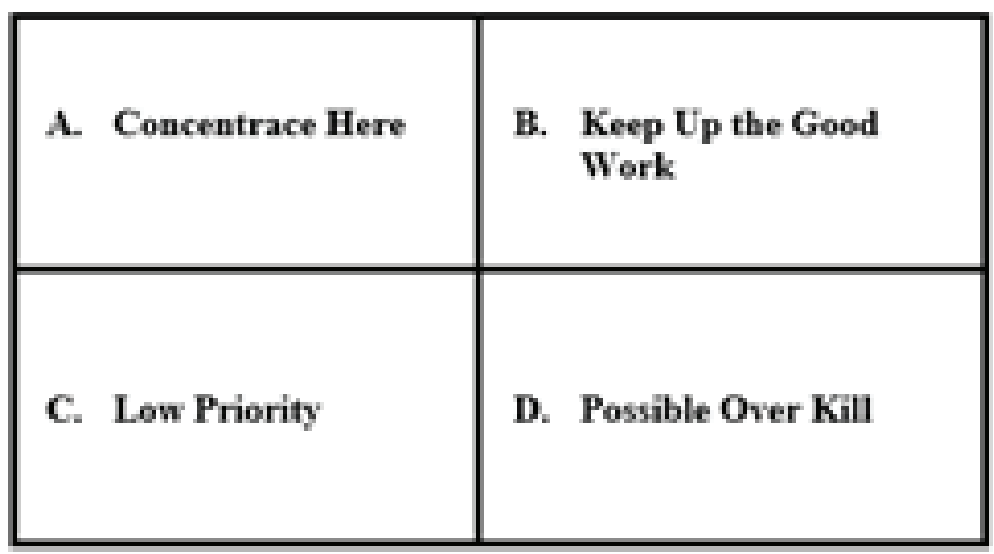

Figure 1: Importance-Performance Analysis (IPA).

for this attribute. Thus, the service given to attributes in this B quadrant is should maintained.

Quadrant C (low priority) in the IPA model describes attributes that are considered unimportant by customers and the company provides low service to customers for this attribute. Therefore, companies give low priority to these attributes.

Quadrant D (possible overkill) describes attributes on that area has low importance for the customer, but the company provides a good services to the customer. Therefore, this area is called an excess area.

\section{Results and Discussion}

A total of 25 valid questionnaires were received, which represents $31.6 \%$ of total population (79 Alumni of Office Administration and Secretary Program-2010 Academic Year). The factors that caused students did not fill out the questionnaire were:

1. An Invalid phone numbers,

2. An Invalid Email,

3. Refuse to complete the filled.

\subsection{Sample descriptions}

Table 1 shows the sample distribution for our sample, Alumni of Office Administration and Secretary Program-2010. Of the sample, most the alumni were female (96.0\%), studied in West Java High Schools (48.0\%), and have an average Colleges GPA more than 3.50 on a 4.0 scale (52.0\%). Slightly, when students apply to an Universities, Office 
TABLE 1: Sample distribution by total 25 alumni of office administration and secretary program-2010.

\begin{tabular}{|c|c|}
\hline & Column \% \\
\hline \multicolumn{2}{|l|}{ Gender } \\
\hline Female & 96.0 \\
\hline Male & 4.0 \\
\hline \multicolumn{2}{|c|}{ High School Background by Provinces } \\
\hline Banten & 12.0 \\
\hline Jakarta & 36.0 \\
\hline East Java & 4.0 \\
\hline West Java & 48.0 \\
\hline \multicolumn{2}{|c|}{ When apply, Program Study is an } \\
\hline Option No. 1 & 24.0 \\
\hline Option No. 2 & 36.0 \\
\hline Option No. 3 & 20.0 \\
\hline Option No. 4 & 12.0 \\
\hline Option No. 5 & 9.0 \\
\hline \multicolumn{2}{|c|}{ Colleges Report GPA (on a 4.0 Scale) } \\
\hline 2.75 & 4.0 \\
\hline $3.01-3.50$ & 44.0 \\
\hline$>3.50$ & 52.0 \\
\hline
\end{tabular}

Administration and Secretary Program is an option number two (36.0\%), and about one quarter of them made Office Administration and Secretary Program Universitas Indonesia as an option number one.

\subsection{Gaps competency}

Table 2 shows about percentage of alumni perceptions of their performance for 12 competencies as key attributes and the importance of these attributes. First, leadership is the one of attributes that they are really competence at, and these attribute is very necessary in working world.

Then, most alumni's said that they are competence in several attributes and these attributes are very necessary to support their work in industry. The Attributes in question are General knowledge, English, Computer, Teamwork, Oral communication 
skills, written Communication skills, Community Empowerment, Specific practical knowledge, and Organizational Management.

Nevertheless, the majority of alumni feel that they are competence in several attributes but those attributes are less necessary in industry where they are working at. The attributes are competencies in research methodology or scientific writing and specific theoretical knowledge.

After the sample perceptions, is intended to make an analysis ImportancePerformance applied to 12 competencies, methodology already explained earlier. The analysis is useful to check not only the importance that students attach to different competencies, as well as their performance on these competencies in industry where they are working at.

According to the Table 3, the competencies that alumni mentioned as the most importance for supporting their work in industry were computer (3.88) in the first place and oral communication skills (3.84) in the second place.

The mean importance for all the 12 competencies was rated at 3.61, whereas the mean of performance jus an average of 3.27. Therefore, if we were to plot the importance and performance on the IPA grid, Office Administration \& Secretary Program Universitas Indonesia would be able to quickly identify competencies that should improve for suitability of undergraduate competence with the need of industries. These is reflected in the IPA shown in Figure 2.

Importance-Performance matrix is represented in Figure 2. So, bearing in mind a study of Wong, Hideki, \& George (2011) is indispensable to do an analysis based on the overall mean level of importance and performance. These authors suggest that should still be considered the mean level of the data reported to cross the axes. Can thus be observed four different quadrants being the axis defined by the global mean level $(3.61 ; 3.27)$ for the attributes.

The results are spread over 4 quadrants (Figure 2). In Quadrant A there are two competencies, General Knowledge and English. These competencies are a paramount importance for students and the Program should improve those competencies to meet with industry needs.

Quadrant B covers the most competencies. There are six competencies in the quadrant, the competencies are computer, teamwork, Oral communication skills, Written Communication skills, Organizational Management, and Leadership. These competencies are important for students and alumni has a good performance on these competencies. So, the Program should continue to work to meet the needs of the working world. 
TABLE 2: Importance and Performance of 12 competencies based on alumni perceptions.

\begin{tabular}{|c|c|c|c|c|}
\hline \multicolumn{5}{|c|}{ Importance \% } \\
\hline Competency & Not necessary & Less necessary & Necessary & Very necessary \\
\hline C1 General knowledge & 0.0 & 0.0 & 36.0 & 64.0 \\
\hline C2 English & 0.0 & 4.0 & 16.0 & 80.0 \\
\hline C3 Computer & 0.0 & 0.0 & 12.0 & 88.0 \\
\hline $\begin{array}{l}\text { C4 Research } \\
\text { methodology/Scientific } \\
\text { writing }\end{array}$ & 0.0 & 28.0 & 40.0 & 32.0 \\
\hline C5 Teamwork & 0.0 & 0.0 & 32.0 & 68.0 \\
\hline $\begin{array}{l}\text { C6 Oral communication } \\
\text { skills }\end{array}$ & 0.0 & 0.0 & 16.0 & 84.0 \\
\hline $\begin{array}{l}\text { C7 Written } \\
\text { Communication skills }\end{array}$ & 0.0 & 0.0 & 28.0 & 72.0 \\
\hline $\begin{array}{l}\text { C8 Community } \\
\text { Empowerment }\end{array}$ & 0.0 & 8.0 & 44.0 & 48.0 \\
\hline $\begin{array}{l}\text { C9 Specific theoretical } \\
\text { knowledge }\end{array}$ & 0.0 & 8.0 & 48.0 & 44.0 \\
\hline $\begin{array}{l}\text { C10 Specific practical } \\
\text { knowledge }\end{array}$ & 0.0 & 4.0 & 40.0 & 56.0 \\
\hline $\begin{array}{l}\text { C11 Organizational } \\
\text { Management }\end{array}$ & 0.0 & 0.0 & 32.0 & 68.0 \\
\hline C12 Leadership & 0.0 & 4.0 & 24.0 & 72.0 \\
\hline \multicolumn{5}{|c|}{ Performance \% } \\
\hline Competency & $\begin{array}{l}\text { Unconscious } \\
\text { incompetence }\end{array}$ & $\begin{array}{l}\text { Conscious } \\
\text { incompetence }\end{array}$ & $\begin{array}{l}\text { Conscious } \\
\text { competence }\end{array}$ & $\begin{array}{l}\text { Unconscious } \\
\text { competence }\end{array}$ \\
\hline C1 General knowledge & 0.0 & 0.0 & 76.0 & 24.0 \\
\hline C2 English & 0.0 & 12.0 & 56.0 & 32.0 \\
\hline C3 Computer & 0.0 & 8.0 & 48.0 & 44.0 \\
\hline $\begin{array}{l}\text { C4 Research } \\
\text { methodology/Scientific } \\
\text { writing }\end{array}$ & 0.0 & 32.0 & 60.0 & 8.0 \\
\hline C5 Teamwork & 0.0 & 0.0 & 56.0 & 44.0 \\
\hline $\begin{array}{l}\text { C6 Oral communication } \\
\text { skills }\end{array}$ & 0.0 & 4.0 & 56.0 & 40.0 \\
\hline $\begin{array}{l}\text { C7 Written } \\
\text { Communication skills }\end{array}$ & 0.0 & 4.0 & 60.0 & 36.0 \\
\hline $\begin{array}{l}\text { C8 Community } \\
\text { Empowerment }\end{array}$ & 0.0 & 8.0 & 72.0 & 20.0 \\
\hline $\begin{array}{l}\text { C9 Specific theoretical } \\
\text { knowledge }\end{array}$ & 0.0 & 8.0 & 60.0 & 32.0 \\
\hline $\begin{array}{l}\text { C10 Specific practical } \\
\text { knowledge }\end{array}$ & 0.0 & 8.0 & 48.0 & 44.0 \\
\hline $\begin{array}{l}\text { C11 Organizational } \\
\text { Management }\end{array}$ & 0.0 & 0.0 & 60.0 & 40.0 \\
\hline C12 Leadership & 0.0 & 16.0 & 40.0 & 44.0 \\
\hline
\end{tabular}


TABLE 3: Importance-Performance ratings for competencies.

\begin{tabular}{|c|c|c|c|c|}
\hline \multirow[b]{2}{*}{ Competency } & \multicolumn{2}{|c|}{ Importance $^{a}$} & \multicolumn{2}{|c|}{ Performance $^{b}$} \\
\hline & Mean & Level & Mean & Level \\
\hline C1 General knowledge & 3.64 & 0.91 & 3.24 & 0.81 \\
\hline C2 English & 3.76 & 0.94 & 3.20 & 0.80 \\
\hline C3 Computer & 3.88 & 0.97 & 3.36 & 0.84 \\
\hline C4 Research methodology/Scientific writing & 3.04 & 0.76 & 2.76 & 0.69 \\
\hline C5 Teamwork & 3.68 & 0.92 & 3.44 & 0.86 \\
\hline C6 Oral communication skills & 3.84 & 0.96 & 3.36 & 0.84 \\
\hline C7 Written Communication skills & 3.72 & 0.93 & 3.32 & 0.83 \\
\hline c8 Community Empowerment & 3.40 & 0.85 & 3.12 & 0.78 \\
\hline C9 Specific theoretical knowledge & 3.52 & 0.84 & 3.36 & 0.81 \\
\hline C10 Specific practical knowledge & 3.52 & 0.88 & 3.36 & 0.84 \\
\hline C11 Organizational Management & 3.68 & 0.92 & 3.40 & 0.85 \\
\hline C12 Leadership & 3.68 & 0.92 & 3.28 & 0.82 \\
\hline Total Average & 3.61 & 0.90 & 3.27 & 0.81 \\
\hline
\end{tabular}

On the other side, in Quadrant C there are Research Methodology and Community Empowerment, which means that competencies are in the Low Priority. Students performance is below average but it's not considered as an important competencies that need in industry. Shows low importance and low satisfaction with these attributes so do not require additional efforts.

Competencies that appeared in Quadrant D are Specific theoretical knowledge and Specific practical knowledge. It thus appears that these competencies have a below average importance for the same students, is below average, indicating that these competencies not really need in industry. Should receive attention by the Program, but there should be a balanced consideration not to be wasting excessive strain.

This research study managed to provide useful recommendations for Office Administration \& Secretary Program Universitas Indonesia for curriculum development strategies in the future. The IPA grid reveals areas of strategic focus, that is, Concentrate Here quadrants 'Quadrant $A$ ' with findings in this area that require the greatest attention. Also, to be highlighted in this article is that the identification of those who 
judge the importance and performance of each of the benefits is clear because the Office Administration \& Secretary Program's alumni members are only respondents that have worked were asked to complete the survey.

Therefore, competencies in 'Quadrant A' that need to has a greatest attention are General Knowledge and English. Bearing in mind with Paul and Murdoch (1992), in the face of competition in working world, an undergraduate students must be equipped with the following soft skills qualifications:

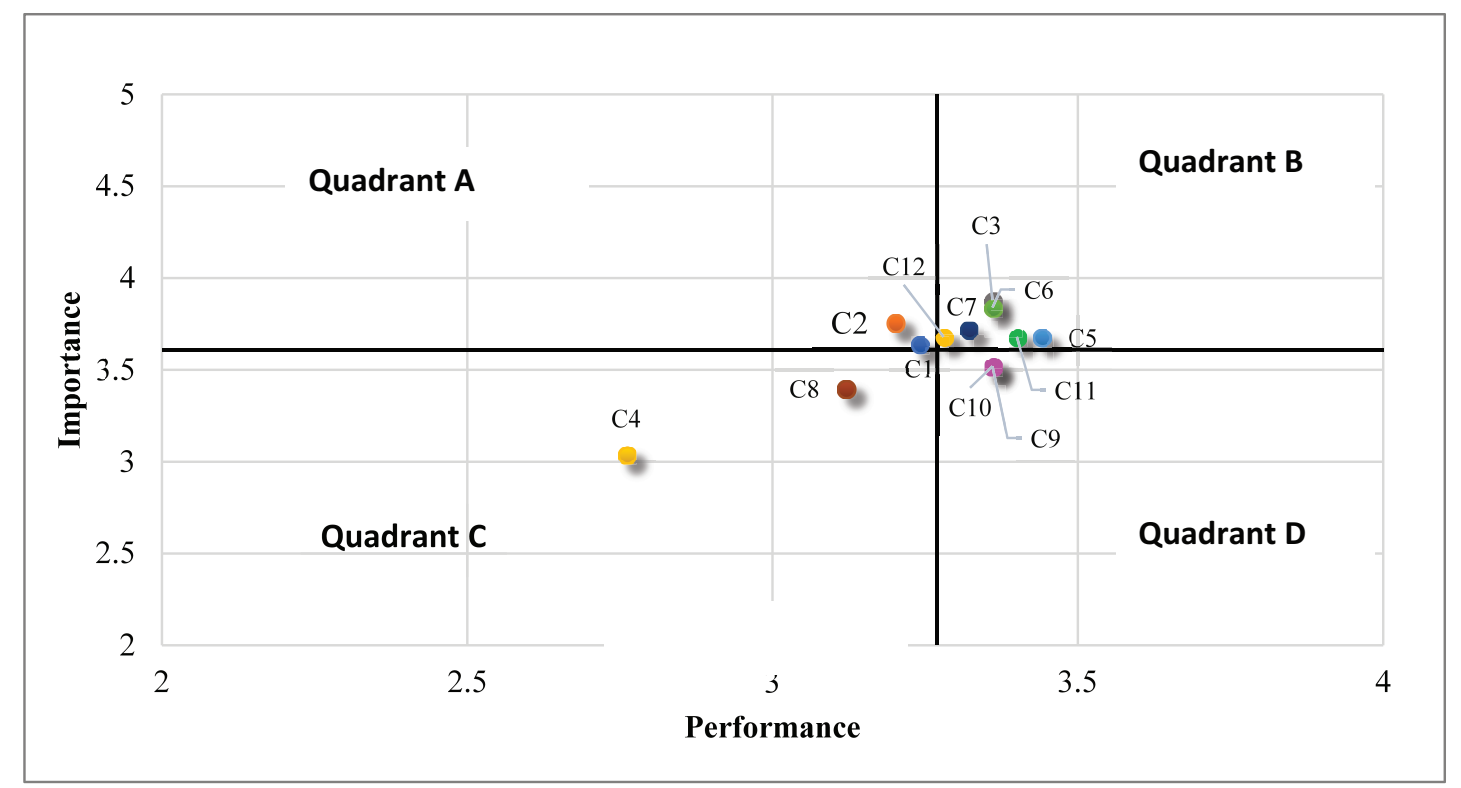

Figure 2: IPA for the global average, according to the mean value for the axis.

1. General knowledge and proficient in English.

2. Communication skills include proficient in computers and the internet, audiovisual presentations, and other communication tools.

3. Personal skills include independence, communication, listening, courage, passion and being able to work together in teams.

4. Desire to move forward as a leader while has the ability to adapt to changes in time and environment.

Recommended by Hartiwi, Herpratiwi, \& Sudirman (2013), to survive in working world because of the weakness in English skills, the Universities can educate the students by Information Gap Task methods. Information Gap Task can be done with the following techniques: roleplay, interview, and games. Those techniques were asked to students with an interesting topic, in addition the student can developed acquisition 
of language, especially for proficient in vocabulary that can make students fluent in applying English communication.

\section{Conclusion}

Based on the research, there are some things that need to be a concern among others. First, for the gap competencies of student abilities and industry needs that require a special attention is in 'Quadrant A'. Those competencies are General Knowledge and Proficient in English.

Second, on the qualitative methods, can be seen there are some competencies that is required by industry needs and Alumni are still Conscious Incompetence on that competencies. The competencies in question are computer and other soft skills. Most of Alumni expected more practice and experience in computer is multiplied.

Lastly, in the process to improve English skills, Office Administration and Secretary Program Universitas Indonesia can use the Information Gap Task methods.

\section{References}

[1] Gasperz, V. (2005). Total Quality Management. Jakarta: PT Gramedia Pustaka.

[3] Hartiwi, J., Herpratiwi, \& Sudirman. (2013). Peningkatan keterampilan Berbicara Bahasa Inggris. Jurnal Teknologi Informasi Komunikasi Pendidikan, 1(2).

[3] Kartikasari, D., Sinarti, Hidayat, R., \& Irsutami. (2014). Analisis Persaingan Pendidikan Tinggi Di Batam Dari Perspektif Politeknik Batam. Cakrawala Pendidikan Th. XXXIII, No. 2, 211-224.

[4] Martilla, J. A., \& James, J. C. (1977). Importance-Performance Analysis. Journal of Marketing, 77-79.

[5] Muhson, A., Wahyuni, D., Supriyanto, \& Mulyani, E. (2012). Analisis Relevansi Lulusan Perguruan Tinggi Dengan Dunia Kerja. Jurnal Economia, 42-52.

[6] Prasetya, Y., Effendy, N., \& Halim, L. V. (2013). Penyusunan Instrumen Pengukuran Kompetensi Non-Teknis Berbasis Wawancara BBI. Jurnal Ilmiah Mahasiswa Universitas Surabaya, 1-16.

[7] Robinson, W. (1974, July). Conscious Competency - The Mark of A Competent Instructor. The Personnel Journal - Baltimore, 53, 538-539.

[8] Sanjaya, W. (2009). Perencanaan dan Desain Sistem Pembelajaran. Jakarta: Kencana Prenadamedia Group. 
[9] Sedarmayanti. (2009). Sumber Daya Manusia dan Produktivitas Kerja. Bandung: Bandar Maju.

[10] Silva, F., \& Fernande, P. O. (2011). Importance-Performance Analysis As A Tool In Evaluating Higher Education Service Quality: The Empirical Results Of Estig (IPB). The 17th IBIMA Internationl Conference Proceedings, (pp. 306-315).

[11] Sugiyono. (2009). Metode Penelitian Kuantitatif, Kualitatif dan R\&D. Bandung: Alfabeta.

[12] Wong, M., Hideki, N., \& George, P. (2011). The Use of Importance-Performance Analysis (IPA) in Evaluating Japan's E-government Services. Journal of Theoretical and Applied Electronic Commerce Research, 6(2), 17-30. doi:10.4067/So71818762011000200003 